\title{
IMPLIKASI PENERAPAN PERMENPAN RB NO.6 TH 2014 PADA PERAN HUMAS PEMERINTAH PROVINSI BANGKA BELITUNG
}

\author{
Rahmadini Rosalia, Anang Sujoko, Maulina Pia Wulandari \\ Communication Departemen, Faculty Of Social and Political Science, \\ Brawijaya University \\ Rahmadinirosalia.sik@gmail.com, anangsujoko@gmail.com, \\ maulinapiawulandari@gmail.com
}

\begin{abstract}
This research uses interpretative paradigm with qualitative method through data collection techniques in the form of in-depth interviews. The discussed phenomenon through qualitative descriptive frames were public relations practices that occurred in Bangka Belitung Province government by targeting public relations expert-level institutions, and skilled level institutions of public relations as a research subject that was reinforced with department heads and the assessment team as professionals are considered able to provide an assessment of the role of institutions of public relations aim to strengthen and obtain the deep of data. Total respondents were 38 people selected through purposive sampling with details social institution 20 people and experts as many as 9 people, added by 4 heads of agencies that were superior institution of public relations, as well as 5 people who assessed the dupak directly. The results showed that the public relations practices in Bangka Belitung were measured through categorization namely the understanding of public relation practitioners to define the public relations and its duties, the position and role of public relations practitioners in each agency, vertical and horizontal responses accepted by public relations practitioners in agencies, and the communication model in the scope of the Provincial Government of Bangka Belitung has not ideal yet. The public relations practice that refers to the Permenpan-RB standard cannot yet be maximally implemented because it is constrained by many factors including the superior policy factor. Meanwhile the implications of the implementation of Permenpan-RB are the facilities of public relations in carrying out their duties because the Permenpan is the reference standard. The public relations tasks are also directed, focused and planned. Permenpan-RB is also a legal basis for Bangka Belitung's public relations in their steps.
\end{abstract}

Keywords : Public relations roles, technical roles, government managers, public relations, Broom and Dozier

Abstrak
Penelitian ini menggunakan paradigma interpretatif dengan metode kualitatif melalui
teknik pengumpulan data dalam bentuk wawancara mendalam. Fenomena yang dibahas
melalui kerangka deskriptif kualitatif adalah praktik hubungan masyarakat yang terjadi
di pemerintah Provinsi Bangka Belitung dengan menargetkan lembaga tingkat
kehumasan hubungan masyarakat, dan lembaga hubungan masyarakat tingkat
keterampilan sebagai subjek penelitian yang diperkuat dengan kepala departemen dan tim
penilai sebagai profesional. dianggap mampu memberikan penilaian terhadap peran
lembaga kehumasan yang bertujuan memperkuat dan memperoleh kedalaman data. Total
responden 38 orang yang dipilih melalui purposive sampling dengan rincian lembaga 
sosial 20 orang dan pakar sebanyak 9 orang, ditambah oleh 4 kepala lembaga yang merupakan lembaga humas unggul, serta 5 orang yang menilai dupak secara langsung. Hasil penelitian menunjukkan bahwa praktik hubungan masyarakat di Bangka Belitung diukur melalui kategorisasi yaitu pemahaman praktisi hubungan masyarakat untuk mendefinisikan hubungan masyarakat dan tugasnya, posisi dan peran praktisi hubungan masyarakat di setiap lembaga, respons vertikal dan horizontal yang diterima oleh publik. praktisi hubungan dalam lembaga, dan model komunikasi dalam lingkup Pemerintah Provinsi Bangka Belitung belum ideal. Praktik hubungan masyarakat yang mengacu pada standar Permenpan-RB belum dapat diimplementasikan secara maksimal karena dibatasi oleh banyak faktor termasuk faktor kebijakan superior. Sementara itu implikasi dari implementasi Permenpan-RB adalah fasilitas humas dalam menjalankan tugasnya karena Permenpan adalah standar acuan. Tugas PR juga diarahkan, fokus, dan terencana. Permenpan-RB juga merupakan dasar hukum bagi hubungan masyarakat Bangka Belitung dalam langkah-langkah mereka.

Kata kunci:

Peran humas, peran teknis, manajer, humas pemerintah, Broom dan Dozier

\section{Pendahuluan}

Humas (Hubungan Masyarakat) di Pemerintah Provinsi Bangka Belitung mengharapkan humas dapat menjadi jurnalis dalam mengomunikasikan berbagai kebijakan pemerintah pada publik eksternal maupun internal dengan membawa nama baik masing-masing instansi (Megawandi, 2018). Hal ini ditunjukkan humas dengan hasil kerja website dan beberapa koran lokal serta pemberitaan pada media RRI secara produktif. Pemerintah bahkan menerbitkan SK Gubernur pembentukan Tim Komunikasi Gubernur pada tanggal 21 September 2016. Tim yang beranggotakan pranata humas serta beberapa wartawan senior ini menjadi kanal yang bersinergi dengan humas di seluruh Organisasi Perangkat Daerah
(OPD) Provinsi Kepulauan Bangka Belitung.

Hal ini dilakukan utamanya untuk menangkal sekaligus menyeimbangkan tren pemberitaan negatif dengan pemberitaan positif melalui optimalitas penggunaan website resmi provinsi maupun website di masing-masing OPD sebagai wujud kerja jurnalis. Tujuannya tidak lain adalah publikasi pemberitaan terkait transparansi informasi dan program kerja serta kebijakan pemerintah sesuai dengan semangat UU Republik Indonesia No.14 Tahun 2008 tentang. Keterbukaan Informasi yang menuntut pemerintah untuk menyediakan serta memberikan informasi publik seluas-luasnya kepada masyarakat secara terbuka, mudah, murah, dan sederhana (Kementerian Negara Pendayagunaan Aparatur Negara dan 
Reformasi Birokrasi, 2011). Sejalan dengan hal itu maka, informasi publik harus bersifat terbuka dan memiliki aksesibilitas luas sehingga diharapkan mampu menstimulus partisipasi masyarakat dalam program kerja serta kebijakan pemerintah yang transparan, efektif, efisien, akuntabel dan bertanggungjawab (Kriyantono, 2015; Nelisna, 2014)

Merujuk pada hal tersebut, publikasi informasi di Provinsi Kepulauan Bangka Belitung kemudian menjadi penting karena letak geografis wilayahnya yang terpisah pulau yaitu Pulau Bangka dan Pulau Belitung serta pulau-pulau lain dengan total pulau bernama 470 buah dan yang berpenghuni 50 buah (Pemerintah Provinsi Kepulauan Bangka Belitung, 2017), mengharuskan pemerintah bekerja ekstra dalam proses penyebaran informasi hingga sampai ke pelosok wilayah provinsi. Ditambah lagi sebagai salah satu provinsi termuda di Indonesia, Bangka Belitung sedang gencar mempromosikan dirinya terkait semua bidang, sehingga optimalisasi peran humas sebagai jurnalis gencar diserukan pemerintah.

Akan tetapi hal di atas secara bersamaan seolah menegaskan bahwa tupoksi humas hanyalah publikasi informasi atas kebijakan dan program kerja pemerintah semata. Padahal menurut Permenpan-RB No.6 Tahun 2014 tentang Jabatan Fungsional Pranata Humas dan Angka Kreditnya, tugas humas sangat kompleks. Dipaparkan bahwa tugas pokok pranata humas meliputi tugas, tanggung jawab dan wewenang dalam melaksanakan kegiatan pelayanan informasi dan kehumasan. Pelayanan informasi dan kehumasan yang dimaksud mencakup kegiatan perencanaan, pelayanan informasi, pelaksanaan hubungan internal dan eksternal, audit komunikasi kehumasan, serta pengembangan pelayanan informasi dan kehumasan. Pada permenpan ini juga dijelaskan bahwa humas memiliki peran eksternal dan internal. Pada lingkup eksternal, humas berperan membina hubungan harmonis dengan lembaga yang ada di masyarakat. Selanjutnya pada konteks internal, humas bertanggung jawab untuk dapat meningkatkan hubungan baik dengan satuan kerja/unit organisasi yang ada di lingkungan pemerintah (Kementerian PAN-RB, 2014). Selain itu, dari 180 butir yang terdapat dalam permenpan No.6 Tahun 2014, peran humas dijabarkan secara luas dan rinci serta tidak sebatas sebagai corong informasi atas segala kebijakan dan program kerja pemerintah. 
Hal ini sejalan dengan teori menurut Broom dan Dozier yang telah meneliti peran humas lebih dari 20 tahun. Broom dan Dozier menjelaskan dengan gamblang peran humas dalam dua kelompok besar, yaitu peran teknisi dan peran manajer. Peran teknisi (communication technitions) mewakili sisi seni dari humas yang kegiatannya menitikberatkan pada pelaksanaan strategi komunikasi secara menyeluruh dalam manajemen. Kegiatan yang termasuk di dalamnya adalah aktivitas menulis, mengedit, mengambil foto, mengelola produksi komunikasi, menyelenggarakan event spesial, serta melakukan kontak intens dengan media, yang dengan kata lain humas disini berperan sebagai journalist in resident. Kemudian sebagai manajer humas berperan membantu organisasi dalam menganalisis dan memecahkan masalah terkait bidang kehumasan, memberi saran kepada manajer senior tentang kebutuhan komunikasi dan bertanggungjawab pada pencapaian organisasi dalam skala luas.

Hal ini semakin diperkuat dengan argumen-argumen teoritis yang menjelaskan bahwa peran humas ideal tidak hanya dijalankan dalam satu lingkup saja seperti peran teknis komunikasi. Argumen ini merujuk pada fakta bahwa fungsi manajemen yang bertugas menilai sikap-sikap publik, mengidentifikasi kebijakan, dan prosedur dari organisasi atas dasar kepentingan publik dan melaksanakan program kerja untuk mendapatkan pengertian dan pengakuan publik (Cutlip, dkk., 2006). Pernyataan ini juga didukung oleh pernyataan yang dikemukakan oleh Berg dan Gibson (2011); Grunig dan Hunt (1984) bahwa humas merupakan fungsi manajemen yang berperan dalam membangun kesepahaman serta menjembatani kepentingan organisasi dengan publiknya yang berfungsi sebagai retorika dan persuasi (Edward, 2006). Definisi di atas secara umum menggambarkan pemahaman dan posisi humas dalam sebuah organisasi, yang dideskripsikan sebagai bentuk manajemen yang khas antara organisasi dengan publik (Isbianti, 2009).

Akan tetapi fakta awal yang peneliti temukan di lapangan bahwa praktik kehumasan di Provinsi Kepulauan Bangka Belitung hanya mengarah pada peran humas sebagai teknisi komunikasi. Oleh karena itu, peneliti merasa penting untuk dapat menggambarkan secara empiris praktik kehumasan di Provinsi kepulauan Bangka Belitung. Salah satu hal yang peneliti ingin gambarkan adalah kekuatan peran humas dalam mengimplementasikan Permenpan-No.6 
Tahun 2014. Secara tersurat peneliti merumuskan masalah penelitian sebagai berikut: Apakah peran humas Bangka Belitung terimplikasi dengan adanya penerapan permenpan dimaksud yang mengindikasi peran humas ideal atau justru sebaliknya?

Melihat dari paparan di atas, urgensi humas harus dapat menjalankan perannya dengan berimbang guna mencapai tujuan komunikasi organisasi, maka humas harus seimbang dalam menjalankan peran teknis maupun peran manajer. Akan tetapi sayangnya ini tidak dipraktikkan dalam aktivitas kehumasan di Pemprov Bangka Belitung dimana pemerintah lebih cenderung memilih satu peran bagi humasnya yakni sebagai teknisi komunikasi. Pada satu sisi, secara teoritis dan telah termaktub dalam permenpan, humas memang harus menjalankan peran teknis dalam fungsi sehari-hari, akan tetapi disaat yang bersamaan humas juga perlu menjalankan peran manajernya. Akan tetapi pada faktanya, ada indikasi di Pemprov Bangka Belitung bahwa humas hanya menjalankan satu peran saja. Maka merujuk pada hal di atas, peneliti merasa perlu melakukan sebuah penelitian untuk dapat membuktikan secara empiris hal tersebut. Penelitian ini juga menjadi penting mengingat belum ada penelitian yang melakukan telaah terhadap fenomena yang kontradiktif meski telah ada aturan dan secara teori menyatakan bahwa humas ideal adalah yang menjalankan fungsinya sebagai teknisi dan manajer.

Selanjutnya, penelitian ini dijalankan dengan menggunakan dua rumusan masalah utama. Pertama, tentang pelaksanaan praktik kehumasan di pemerintah Provinsi Kepulauan Bangka Belitung. Dua, implikasi penerapan Permenpan-RB No.6 Tahun 2014 di wilayah Provinsi Kepulauan Bangka Belitung terhadap praktik kehumasan. Teknik pengumpulan data yang dipakai adalah wawancara mendalam yang dilakukan melalui tatap muka, sambungan telepon dan email. Subjek penelitian ditentukan dengan menggunakan teknik purposive sampling untuk menyeleksi orang-orang dengan kriteria tertentu berdasarkan tujuan penelitian. Kemudian data akan peneliti interpretasikan dengan menggunakan metode interaktif seperti yang dillakukan Miles, Huberman dan Saldana.

\section{Kajian Pustaka}

Cutlip \& Center dalam Kriyantono (2016), menguraikan fungsi humas secara umum dalam organisasi adalah sebagai penunjang kegiatan manajemen dalam 
mencapai tujuan organisasi, untuk kekuasaan ketika memiliki posisi di menginformasikan secara luas kebijakan organisasi kepada publik dan menyampaikan opini publik kepada organisasi untuk menciptakan komunikasi dua arah, melayani publik serta memberikan nasihat kepada pimpinan untuk kepentingan bersama, serta membangun hubungan harmonis antara organisasi dengan publik secara internal maupun eksternal. Sejalan dengan itu, Rachmadi (1994) menjabarkan fungsi humas pemerintah yang paling dasar adalah dengan membantu menegaskan dan mencapai tujuan utama dari pemerintah, meningkatkan respon dan pelayanan pemerintah, dan menyediakan informasi yang cukup tentang pemerintah yang tertuju kepada masyarakat luas.

Menurut Rachmadi (1994), humas seharusnya ditempatkan pada jajaran tertinggi dalam struktur organisasi sehingga memungkinkan pemberian akses kontribusi pada proses pengambilan keputusan yang membuat humas memahami alasan pengambilan keputusan sebagai acuan dalam menentukan tindakan tepat untuk mendukung kebijakan yang dikeluarkan instansi. Humas berada dalam kondisi terbaik bila berfungsi pada tingkat manajemen puncak (Wilcox, dkk., 2011; Kriyantono, 2015), dan mempunyai koalisi dominan serta berpartisipasi dalam proses pengambilan keputusan (Guo dan Anderson, 2018). Ardianto (2004) menekankan signifikansi keberadaan humas dalam jajaran pembuat keputusan sangatlah crucial. Divisi humas menjadi kurang efektif jika fungsi dan perannya tidak terintegratif ke tingkat pimpinan manajemen puncak sebagai pengambil keputusan secara strategis (Dozier, 1992). Cutlip dkk. (2006) mengatakan bahwa jika humas memiliki kedudukan di dalam koalisi dominan, maka humas akan memainkan peran yang lebih besar dalam penentuan pencapaian tujuan organisasi.

Oleh karena hal itu, posisi ideal praktisi humas memiliki andil besar dalam proses pengambilan keputusan yang artinya memiliki kesempatan yang sama dengan manajemen lain untuk duduk bersama dalam proses pengambilan kebijakan organisasi dalam manajemen (Cutlip, dkk., 2006). Hal ini disadari betul oleh Pemerintah Indonesia, sehingga secara khusus Pemerintah Indonesia mengatur model komunikasi Humas Indonesia. Hal ini termaktub dalam Permenpan-RB No.30 tahun 2011 disebutkan bahwa humas pemerintah secara ideal menggunakan model komunikasi dua arah timbal balik simetris 
yang tujuannya untuk menciptakan komunikasi dua arah dengan pengaruh yang seimbang. Hal ini dipicu karena tuntutan reformasi birokrasi terhadap transparansi dan akuntabilitas informasi yang memerlukan komunikasi interaktif (Kementerian PAN-RB, 2011). Pernyataan ini sejalan dengan Grunig yang dalam penelitiannya menggagas komunikasi simetris dua arah sebagai praktik komunikasi ideal dan normatif yang melambangkan humas profesional (Grunig dan Hunt, 1984; Kent dan Taylor, 2007; Grunig, dkk., 2002). Grunig melakukan banyak penelitian tentang sejauh mana organisasi mempraktikkan empat model humas (Sriramesh dan Vercic, 2003). Dalam menjalankan perannya, Grunig dan Hunt (1984) membagi empat model humas yang sering diterapkan dalam organisasi pemerintah maupun non pemerintah yakni: press agentry, public information, two way asimetryc, dan two way simetryc.

Selain perincian tentang model komunikasi humas, Pemrintah Indonesia juga mengatur secara teknis jabatan fungsional humas dan angka kreditnya. Hal tersebut dituangkan melalui Permenpan-RB No.6 Tahun 2014 tentang Jabatan Fungsional Pranata Humas dan Angka Kreditnya yang ditetapkan
Kementerian Pendayagunaan Aparatur Negara dan Reformasi Birokrasi pada tanggal 10 Januari 2014 dan diundangkan pada 4 Maret 2014, menjadi tolok ukur pentingnya peran praktisi humas dalam melaksanakan tugas secara profesional dalam ranah pemerintah. Aturan ini merupakan penyempurnaan dari Permenpan No. Per/109/M.PAN/11/2005 tentang jabatan Fungsional Pranata Humas dan Angka Kreditnya yang dianggap masih terdapat kekurangan dan belum memenuhi tuntutan kebutuhan (Kementerian PAN-RB, 2014), sehingga untuk menyempurnakannya ditambahkan item kegiatan menjadi 180 item kegiatan kehumasan yang telah mengakomodasi pemanfaatan teknologi komunikasi (PranataHumas.Bali). Dikeluarkannya permenpan-RB No.6 Tahun 2014 adalah untuk memenuhi kriteria pranata humas yang profesional, berkompetensi dalam rangka pengembangan karier sesuai dengan standar profesi yang ditunjukkan oleh butir-butir permenpan dengan tujuan dan peran humas ideal dalam mendukung kinerja pemerintah (Idris, 2014).

Merujuk pada hal tersebut dan sebagai bentuk pengoptimalan peran humas di Bangka Belitung, peneliti mengelompokkan butir-butir permenpanRB No.6 Tahun 2014 sesuai dengan 
jenjang jabatan masing-masing. Hal ini akan memberikan gambaran sejauh mana pranata humas dalam mengimplementasikan butir-butir permenpan sebagai acuan pelaksanaan tugas kehumasan sehari-hari. Hasil dari pengelompokan butir-butir permenpan akan diuji melalui teori peran humas Broom dan Dozier untuk mendapatkan gambaran praktik kehumasan di Bangka Belitung dan implikasinya.

\section{Metodologi}

Penelitian ini menggunakan paradigma interpretatif. Tujuannya adalah untuk mencari sebuah pemahaman tentang bagaimana kita membentuk pemaknaan melalui interaksi dan bagaimana bersikap terhadap pemaknaan yang telah kita bentuk (Ardianto dan Q-Anees, 2009). Paradigma ini dijalankan menggunakan metode kualitatif sebagai upaya membantu memahami sebuah fenomena yang terjadi pada praktik kehumasan di pemerintahan Provinsi Kepulauan Bangka Belitung mengacu kepada Permenpan-RB No.6 Tahun 2014 sebagai sebuah realitas. Teknik pengumpulan data yang digunakan adalah wawancara mendalam yang menurut Kriyantono (2006), merupakan metode riset dengan melakukan kegiatan tatap muka secara mendalam dan terus- menerus untuk menggali informasi dari subjek penelitian secara detail.

Selanjutnya, subjek penelitian ini adalah 38 pranata humas di lingkungan pemerintahan Provinsi Kepulauan Bangka Belitung. Jumlah tersebut didapatkan dari teknik sampling purposive. Hal ini mengingat, menurut Kriyantono (2006), digunakan untuk menentukan kriteria yang dapat mendukung tujuan penelitian, yaitu menyeleksi orang-orang dengan kriteria tertentu berdasarkan tujuan penelitian. Hal ini sejalan dengan yang dikatakan Sarosa (2012), dan Bryman (2012) bahwa pemilihan subjek penelitian berdasarkan pada karakteristik dan pertimbangan tertentu dengan tujuan untuk menargetkan orang-orang yang relevan dengan pertanyaan penelitian. Neuman (2013) menambahkan bahwa subjek penelitian yang sesuai dengan kriteria tertentu bersifat representatif.

Adapun kriteria informan yang sesuai dengan penelitian dan akan ditetapkan sebagai subjek penelitian yang pertama adalah informan merupakan pegawai negeri sipil yang berada di wilayah Provinsi, Kabupaten dan Kota Provinsi Kepulauan Bangka Belitung di tiap instansi, kedua, menjabat sebagai fungsional pranata humas dan telah mengumpulkan Dupak (Daftar Usul 
Pengajuan Angka Kredit) minimal satu kali. Pemilihan kriteria pertama ini mengacu kepada tujuan penelitian yang menyasar pranata humas sebagai praktisi humas pemerintah yang mengimplementasikan Permenpan-RB No.6 Tahun 2014 dalam pelaksanaan perannya sehari-hari. Ditetapkannya informan dari tiap wilayah tujuannya adalah agar data yang diperoleh secara menyeluruh, lengkap dan berimbang dengan tingkat kesulitan masing-masing. Telah mengumpulkan Dupak menjadi prioritas peneliti karena melalui pengumpulan Dupak praktisi humas Bangka Belitung membuktikan bahwa meraka telah mengaplikasikan perannya melalui butir-butir permenpan sesuai jenjang jabatan. Selain itu, dengan mempertimbangkan optimalisasi sumber, peneliti juga akan menggali informasi dari praktisi terkait yang berpengaruh dan mendukung kedalaman maupun keluasan data sebagai masukan pada penelitian ini.

\section{Hasil}

Hasil ini akan menyajikan beberapa terkait aktivitas kehumasan yang berjalan di Pemerintahan Provinsi Bangka Belitung. Pertama, tentang pemahaman para praktisi huma tentang aktivitas kehumasan dan tugas-tugasnya. Terlihat ada pemahaman yang berbeda antara PHT, PHA dan KD. PHA dan PHT mendefinisikan humas sebagai praktisi yang mampu menjalankan peran seharihari sesuai dengan tugas pokok dan fungsinya serta menjadi garda terdepan dari publikasi informasi.. PHA dan PHT menyebut bahwa humas harus dapat dilibatkan dalam proses manajemen ataupun kegiatan-kegiatan lintas bidang yang berkaitan dengan kehumasan dan tidak hanya sekedar tugas-tugas teknis, melainkan dalam skala manajer yang perannya sebagai partner kerja atasan ataupun mediator pada substansi eksternal dan internal. Peran atasan sebagai pembuat kebijakan yang berpihak menjadi kunci utama keberhasilan humas menjadi seorang praktisi profesional. Sedangkan KD mendefinisikan humas sebagai sound pemerintah, praktisi yang dapat menjalankan perannya sesuai dengan tugas pokok dan fungsi, yaitu dapat memberikan informasi serta memublikasikan berita atau kegiatan yang berkaitan dengan pemerintah. KD juga beranggapan bahwa humas harus dapat menjadi praktisi yang aktif dan kreatif terhadap perkembangan yang ada.

Selanjutnya, kedua, setelah memahami tentang perbedaan sudut pandang tentang pendefisian kehumasan, 
selanjutnya peneliti memaparkan hasil tentang posisi serta peran dan fungsi para praktisi dalam masing-masing organisasi. Humas yang termasuk ke dalam kategori rumpun jabatan fungsional dalam struktur organisasi pada instansi di Provinsi Kepulauan Bangka Belitung sebagian besar berada tepat di bawah kepala dinas selaku esselon II. Hal ini secara alamiah membuat kedudukan humas sepenuhnya bertanggungjawab kepada kepala dinas. Tetapi pada praktiknya, humas seringkali tidak bertanggungjawab kepada kepala dinas, melainkan kepada sekretaris, kepala bidang atau kepala sub bidang. Beberapa humas di instansi tertentu bahkan tidak pernah berhubungan dengan kepala dinas. Begitu pula dengan pelaksanaan tugas sehari-hari yang tidak selaras dengan kedudukan humas di struktur organisasi.

Pada instansi yang memiliki bidang atau bagian humas tersendiri di dalam kedinasan misal Dinas Kominfo, Biro Humas dan Protokol dan Sekretariat DPRD baik di provinsi maupun kabupaten, pranata humas dengan sendirinya akan ditempatkan pada bagian ini. Biro Humas dan Protokol Setda Provinsi Kepulauan Bangka Belitung, humas ditempatkan di bawah tanggungjawab bagian kehumasan secara langsung. Kemudian Dinas Kominfo
Provinsi dan Bagian Kominfo Kabupaten Belitung Timur menempatkan humasnya di bawah bidang Informasi dan Komunikasi Publik (IKP) karena bidang ini memang berada di dalam instansi Kominfo. Akan tetapi secara struktur organisasi, posisi humas di ketiga instansi ini berada tepat di bawah kepala dinas, walaupun dalam pelaksanaan tugas seharihari bertanggungjawab kepada kepala bidang dan bukan kepala dinas.

Selanjutnya, pada beberapa tugas tertentu, yang terjadi di Kominfo Provinsi adalah sistem protokoler hierarki yakni bentuk penugasan berjenjang melalui kepala sub bidang yang diteruskan kepada kepala bidang. Jika permasalahan dapat terselesaikan dengan baik, hal ini akan terhenti di kepala bidang, dan sebaliknya jika permasalahan dianggap penting maka akan diteruskan ke jenjang yang lebih tinggi yakni kepala dinas. Tidak berbeda jauh dengan Dinas Kominfo Kabupaten Belitung Timur, dimana kedudukan humas di dalam struktur organisasi kontradiktif dengan praktik perannya sehari-hari. Humas berada di bawah Kepala Dinas secara langsung tetapi bertanggungjawab dan mendapat penugasan justru dari Kepala Bidang. Untuk beberapa tugas, humas harus 
melalui kepala sub bidang dengan sistem berjenjang.

Hal ini juga ditegaskan oleh Belli (2018), dalam wawancara menjelaskan bahwa kedudukan humas di dalam struktur organisasi memang berada di bawah Kepala Dinas karena humas sebagai jabatan fungsional bersifat mobile, yang artinya humas harus lebih mudah menjangkau semua bidang. Hal ini menyiratkan peran humas yang fleksibel dan strategis sehingga bisa masuk ke semua lini. Posisi ini memungkinkan humas ditempatkan di mana saja selama posisi tersebut memiliki lajur kehumasan. Jadi, yang paling memungkinkan adalah humas di berdayakan di bawah bidang komunikasi informasi atau bidang humas jika instansi tersebut memilikinya, dan akan ditempatkan di bagian sekretariat jika instansi bersangkutan tidak memiliki bidang komunikasi dan humas sesuai surat tugas kepala dinas.

Merujuk pada beberapa temuan pada hasil wawancara menyebutkan bahwa posisi pada manajemen puncak adalah jabatan struktural berjenjang yang menyebabkan proses pemberian tugas secara terstruktur. Jadi, kedudukan humas dalam struktur organisasi dengan realisasi pelaksanakan tugas sehari-hari lebih baik bila diseragamkan agar tidak terjadi kesalah pahaman tentang kedudukan humas pada setiap wilayah di Provinsi Kepulauan Bangka Belitung. Humas dalam hal ini agar ditempatkan pada posisi yang memungkinkan untuk dapat akses ke segala bidang dengan wewenang yang seharusnya agar humas dapat berperan maksimal dalam instansi dan masyarakat dapat merasakan perannya secara langsung.

Berikutnya, ketiga, data tentang respon vertical dan horizontal yang diterima oleh praktisi humas di organisasi. Dalam membangun hubungan baik secara vertikal antara pranata humas dengan atasannya, baik PHA maupun PHT memandang dengan cara yang sama, yakni atasan yang merespon kehadiran humas dengan positif. Hal ini ditunjukkan atasan dengan tidak membatasi gerak pranata humas dalam berkreasi. Atasan juga lebih banyak memberikan tugas-tugas kehumasan kepada pranata humas.

Berikutnya, masalah interaksi antara atasan dengan pranata humas dalam hal proses pemberian tugas pada tiap instansi akan berbeda-beda karena dipengaruhi oleh pola kinerja atasan yang juga berbeda. Temuan di lapangan menunjukkan bahwa atasan memberikan dukungan yang sama atas kinerja humas dalam instansi meskipun dalam 
pemahaman yang berbeda. KD sebagai atasan memberikan akses yang luas terhadap pranata humas dalam menjalankan tupoksinya selama masih di dalam lajur kehumasan dan tidak meninggalkan tugas-tugas kedinasan. Hal ini sejalan dengan yang dipaparkan pranata humas pada wawancara di lapangan. Akan tetapi hal ini tidak terjadi di semua instansi yang ada di Bangka Belitung.

Pada Dinas Kominfo dan Biro Humas dan Protokol, pranata humas lebih banyak dilibatkan pada tugas-tugas kehumasan yang merupakan tupoksi dari instansi ini, khususnya pranata humas tingkat ahli. Pada instansi ini, pranata humas benar-benar hanya melaksanakan tugas-tugas kehumasan. Sedangkan pada pranata humas tingkat terampil, sebagian kecil masih melaksanakan perintah atasan yang mengarah kepada tugas di luar kehumasan. Jadi, pada kedua instansi ini, pranata humas sebagian besar mulai terfokus kepada tugas-tugas kehumasan saja. Sedangkan pada dinas lain, masih banyak yang belum memfokuskan kinerja pranata humas pada tugas kehumasan, melainkan tetap membebankan pranata humas dengan tugas-tugas diluar tugas kehumasan, baik itu yang bersifat rutinitas, perintah atasan, tugas tambahan, ataupun tugas-tugas dalam bidang tempat pranata humas diperbantukan. Hal ini lebih sering terjadi kepada pranata humas tingkat terampil.

Keempat, sebagai data terakhir yang peneliti sajikan dalam penelitian ini adalah tentang model komunikasi praktik kehumasan di lingkup Pemerintahan Provinsi Bangka Belitung. Merujuk kepada media yang digunakan instansi dalam berkomunikasi dengan masyarakat secara eksternal, pemerintah Provinsi Kepulauan Bangka Belitung menerapkan sistem komunikasi satu arah yang bersifat informatif. Temuan di lapangan menunjukkan bahwa sebagian besar instansi yang ada di Bangka Belitung menerapkan model komunikasi ini. Hal tersebut dapat dibuktikan dengan adanya website di hampir semua instansi. Pemberitaan yang dimuat di website notabene adalah pemberitahuan yang informatif dan tidak membutuhkan feedback, walaupun tetap disediakan kolom pembaca. Temuan lain menunjukkan bahwa beberapa website instansi sepi pengunjung dan bahkan beberapa tidak beroperasi dalam jangka waktu yang lama. Sejauh ini pengelola website tidak berusaha untuk menambah jumlah pengunjung melainkan hanya memastikan berita telah terposting dan 
melihat seberapa banyak pengunjung yang membuka website.

Disamping itu, sebagian instansi melalui pranata humas aktif mengelola media sosial seperti facebook, twitter, dan instagram dalam memublikasikan berita terkait instansi. Melalui media sosial biasanya lebih mudah untuk mendapatkan respon publik berupa komen, like, ataupun share dibandingkan dengan website. Media sosial yang paling banyak digunakan adalah facebook. Hanya saja jenis media komunikasi media sosial ini belum bersifat resmi dan lebih kepada kreatifitas dari pranata humas itu sendiri. Media sosial di instansi juga banyak yang terbengkalai dan tidak dikelola dengan baik. Akan tetapi media sosial jenis ini kadang menjadi tidak tepat sasaran dan bias karena pemberitaan bukanlah ditujukan kepada pembaca di media sosial, melainkan masyarakat terkait program kerja yang dilaksanakan instansi. Hanya saja media sosial lebih mudah diakses dan lebih populer dibandingkan dengan website pemerintah.

Walaupun ada feedback yang diberikan dari pemberitaan di media sosial, tetapi media sosial ini belum bisa dikatakan dikatakan dua arah karena sampai saat ini belum ada respon atraktif antara pembaca dengan pengelola media sosial. Dan meskipun respon yang diberikan pembaca masih sangat jarang, tetapi model komunikasi media sosial sudah mulai mengarah kepada komunikasi dua arah secara simetris jika dibandingkan dengan interaksi yang terjadi di website. Pada beberapa tulisan yang dimuat di laman facebook, terlihat respon yang diberikan pembaca dengan mengajukan pertanyaan terkait berita dimaksud. Beberapa tautan yang dibagikan juga dishare kembali oleh pembaca. Hal ini menunjukkan media sosial lebih ditanggapi dibandingkan dengan website.

\section{Discussion}

Data wawancara menunjukkan bahwa kehadiran humas di instansi yang ada di Bangka Belitung berada pada posisi yang tidak krusial. Peran dan fungsi humas di analogikan sebagai aktifitas teknis dalam publikasi kehumasan yang dapat dilakukan oleh bidang lain di luar kehumasan. Dengan kata lain, humas kerap disebut sebagai jurnalis, tukang foto atau pencari berita. Fungsi humas sebagai bagian dari komunikasi dalam organisasi secara absolut penting bagi kelangsungan setiap organisasi (Ardianto, 2004) tidak terjadi. Karena dalam menjalankan perannya, humas bergantung kepada kebijakan atasan yang menjadi kunci dari 
optimalisasi peran humas pada aktifitasnya sehari-hari.

Untuk itu, kebijakan atasan menentukan sejauh mana keterlibatan humas dalam tiap kegiatan ataupun manjemen. Sejauh ini yang terjadi adalah humas tidak dilibatkan dalam proses manjerial pada jajaran manajemen puncak manapun. Humas hanya aktif menjalankan peran teknisnya. Sedangkan Cutlip \& Center (dalam Kriyantono, 2016; Morissan, 2014), menguraikan fungsi humas secara umum dalam organisasi adalah sebagai penunjang kegiatan manajemen dalam mencapai tujuan organisasi, untuk menginformasikan secara luas kebijakan organisasi kepada publik dan menyampaikan opini publik kepada organisasi untuk menciptakan komunikasi dua arah, melayani publik serta memberikan nasihat kepada pimpinan untuk kepentingan bersama.

Humas di Bangka Belitung telah melaksanakan peran dalam menginformasikan segala kegiatan pemerintah walaupun masih bersifat satu arah. Tetapi, humas belum dilibatkan dalam kegiatan manajemen untuk mencapai tujuan organisasi ataupun sebagai penasihat atasan. Padahal, humas seharusnya berkontribusi secara efektif pada lembaga pemerintah, sehingga untuk itu pemerintah harus memberdayakan humas sebagai fungsi manajemen yang penting pada tingkat strategis dan manajerial serta mendukung penuh kegiatannya (Sriramesh dan Vercic, 2003; Meintjes dan Grobler, 2014).

Keadaan ini sedikit banyak juga bergantung pada respon pimpinan terhadap segala aktivitas praktisi kehumasan. Hal ini terjadi pada Dinas Kominfo dan Biro Humas dan Protokol serta Sekretariat DPRD di Kabupaten maupun Provinsi. Di satu sisi, humas menjadi aktif serta produktif terutama pada peran teknis melalui publikasi informasi terkait peliputan dan pemberitaan instansi. Di sisi lain, humas menjadi tidak produktif karena kehadiran tenaga struktural yang menjalankan peran kehumasan.

Respon ini lah yang pada akhirnya juga turut memengaruhi model komunikasi kehumasan di lingkungan tersebut. Model komunikasi yang digunakan di Bangka Belitung adalah model komunikasi satu arah yang bersifat informatif dan tidak ada respon timbal balik. Model yang digunakan ini menjadi tidak ideal karena tidak ada feedback terkait berita yang diturunkan sehingga pemerintah tidak pernah tahu respon apa yang diberikan oleh masyarakat. Terkait 
perannya, humas tidak memiliki kapasitas terkait proses interaktif dari setiap pemberitaan yang dikeluarkan karena tidak ada wewenang dalam jajaran koalisi dominan.

Keadaan ini juga terus terjadi karena ditemukannya sebuah fakta tentang posisi humas dalam organisasi. Selama ini, posisi humas dalam struktur organiasi di Provinsi Kepulauan Bangka Belitung berada tepat di bawah esselon II atau kepala dinas. Hal ini menunjukkan posisi humas yang strategis dalam struktur organisasi. Grunig (1992, dalam Moss, Likely, Sriramesh dan Ferrary, 2017) menyampaikan bahwa struktur organisasi berfungsi dalam menentukan peran dan ruang lingkup kegiatan yang dapat dilakukan oleh humas yang pada akhirnya akan meningkatkan pengaruh mereka dalam organisasi. Struktur organisasi terbaik akan memaksimalkan fungsi humas dalam mencapai tujuan organisasi. Jadi, posisi humas dalam struktur organsisasi menentukan posisi penting humas di dalam instansi. Tetapi, dalam realisasi pelaksanaan tugas sehari-hari, humas di Bangka Belitung justru lebih banyak bertanggungjawab kepada sekretaris, kepala bidang atau kepala sub bidang yang di dalam struktur organisasi kedudukannya berada di bawah pranata humas. Alasannya, agar akses pelaksanaan tugas humas menjadi lebih dekat, cepat, efektif dan efisien.

Ketika humas berada pada posisi di bawah sekretariat, bidang atau sub bidang, humas secara otomatis bertanggungjawab penuh terhadap bidang dimana dia ditempatkan. Hal ini menjadi kontradiktif mengingat posisi humas yang berada langsung di bawah kepala dinas dan lebih tinggi kedudukannya dibanding bidang tersebut. Tetapi secara administrasi, humas menjadi lebih mudah untuk berinteraksi terkait penugasan perannya sehari-hari. Tugas yang diberikan atasan, dalam hal ini sekretaris, kepala bidang atau kepala sub bidang bisa langsung dilaksanakan dan atasan menjadi lebih mudah untuk memberikan perintah kepada humas.

Kondisi ini relatif sejalan dengan Pergub Kepulauan Bangka Belitung No.58 tahun 2016 tentang Kedudukan, Susunan Organisasi, Tugas Dan Fungsi, Serta Tata Kerja Dinas Daerah Provinsi Kepulauan Bangka Belitung bab XXVI pasal 456 butir (3) yang berbunyi pejabat fungsional dalam melaksanakan tugasnya bertanggungjawab langsung kepada kepala dinas. Pada butir (6) di pasal yang sama menyebut bahwa pembinaan administratif jabatan fungsional 
diselenggarakan oleh sekretaris dinas meliputi penilaian dan penetapan angka kredit, usulan kenaikan pangkat, gaji berkala serta pendidikan dan pelatihan. Kemudian pada butir (7) menegaskan bahwa pembinaan teknis jabatan fungsional diselenggarakan oleh kepala bidang terkait meliputi rencana penugasan dan pengukuran kinerja.

Hal ini membuat humas kehilangan kewenangannya pada jajaran manajemen puncak dan menjalankan tugas melalui sistem hierarki berjenjang. Sedangkan menurut Cutlip dkk. (2006) bahwa jika humas memiliki kedudukan di dalam koalisi dominan, maka humas akan memainkan peran yang lebih besar dalam penentuan pencapaian tujuan organisasi Namun, dalam menjalankan perannya humas justru dipengaruhi oleh perintah atasan dan tugas-tugas lain terkait bidang dimana humas ditempatkan. Seperti yang disampaikan Rachmadi (1994), humas seharusnya ditempatkan pada jajaran tertinggi dalam struktur organisasi sehingga memungkinkan pemberian akses kontribusi pada proses pengambilan keputusan yang membuat humas memahami alasan pengambilan keputusan sebagai acuan dalam menentukan tindakan tepat untuk mendukung kebijakan yang dikeluarkan instansi. Tetapi yang terjadi, posisi strategis humas Bangka Belitung dalam struktur organisasi tidak berpengaruh terhadap kontribusinya di jajaran top manajemen. Humas sebaliknya, tidak memiliki kewenangan apapun dalam proses pengambilan keputusan. Sedangkan signifikansi keberadaan humas dalam jajaran pembuat keputusan sangatlah crucial (Ardianto, 2004). Hal ini relatif tidak sesuai dengan pernyataan Guo dan Anderson, (2018) yang menyatakan bahwa humas mempunyai kekuasaan ketika memiliki posisi di koalisi dominan serta berpartisipasi dalam proses pengambilan keputusan.

Berdasarkan penjelasan di atas, tersirat bahwa kedudukan dan peran humas di Provinsi Kepulauan Bangka Belitung belum dapat dikatakan ideal karena belum adanya keselarasan antara kedudukan humas di dalam struktur organisasi dengan kewenangannya dalam pelaksanaan peran sehari-hari. Dalam hal ini, pemerintah Provinsi Kepulauan Bangka Belitung telah merujuk kepada pergub tentang pengaturan posisi dan kedudukan humas yang disesuaikan dengan kebutuhan dan kondisi spesifik instansi yang melatarbelakangi. Masingmasing instansi memiliki tujuan berbeda 
yang dapat menunjang tercapainya konsep tujuan organisasi.

\section{Simpulan}

Tupoksi pranata humas di Pemerintah Provinsi Kepulauan Bangka Belitung baik tingkat ahli maupun terampil cenderung kepada tugas-tugas yang bersifat teknis dan belum merambah kepada ranah manajer walaupun secara eksplisit telah termaktub dengan jelas di dalam Permenpan-RB No.6 Tahun 2014. Selain itu pranata humas juga masih menjalankan tugas-tugas tambahan di luar dari tugas kehumasan melalui perintah atasan ataupun tugas pada bidang dimana humas ditempatkan. Tetapi dengan adanya Permenpan-RB No.6 Tahun 2014, tugas humas menjadi lebih jelas, terarah dan fokus karena dalam menjalankan perannya, humas menyesuaikan tugas tersebut dengan butir-butir yang ada. Selain itu Permenpan juga menjadi payung hukum humas dalam bekerja. Akan tetapi, implementasi butir-butir Permenpan pada pranata humas Bangka Belitung sangat rendah. Jadi, walaupun berpatokan kepada Permenpan dalam bekerja, pranata humas tetap melaksanakan tugas yang tidak berkaitan dengan Permenpan tetapi relevan dengan tugas kedinasan.

\section{Daftar Pustaka}

Ardianto, E. (2004). Teori dan metodologi penelitian "public relations". Mediator, 5 (2), 231-141. Diakses dari

https://ejournal.unisba.ac.id/index.p hp/mediator/article/view/1159

Ardianto, E. \& Q-Anees, B. (2009). Filsafat Ilmu Komunikasi. Bandung: PT Remaja Rosdakarya.

Bryman, A. (2012). Social Research Methods. Oxford: OUP.

Berg, K. T. \& Gibson, K. (2011). Hired guns and moral torpedoes: Balancing the competing moral duties of the public relations professional. Prism, 8 (1). Diakses dari

http://www.prismjournal.org/homep age.html

Cutlip, S. M., Center, A. H., \& Broom, G. M. (2006). Effective Public Relations. Jakarta: Kencana Prenada Media Group.

Dozier, D. M. (1992). The Organisational roles of communication and public relations practitioners. Excellence in Public Relations and Communication Management, 327355. Hillsdale, NJ: Lawrence Erlbaum Associates. 
Edwards, H. H. (2006). A rhetorical typology for studying the audience role in public relations communications: The avons 3-day disruption as exlemplar. Journal of Communication, $\quad 56, \quad 836-860$. DOI:10.1111/j.1460-

2466.2006.00322.x

Grunig, J. E. \& Hunt, T. (1984). Managing

Public Relations. America: Holt, Rinehart and Winston, Inc.

Grunig, L. E., Grunig, J. E., \& Dozier, D, M. (2002). Excellent Public Relations and Effective Organizations: A Study of Communication Management iIn Three Countries. London: Lawrence Erlbaum Associates.

Guo, S. J., \& Anderson, L. B. (2018). Workplace adversity and resilience in public relations: Accounting for the live experiences of public relations practitioners. Public Relations Review, 44 (2), 236-246. Diakses dari https://doi.org/10.1016/j.pubrev.201 8.02 .002

Isbianti, P. (2009). Peran Humas Sebagai Upaya Menjalin Kerjasama Antara SMK dengan Dunia Usaha/Dunia Industri (DU/DI). Jurnal
Manajemen Pendidikan, 1 (5), 4154.

Idris, I. K. (2014). Peran humas pemerintah di era keterbukaan informasi (analisis isi PermenpanRb No.6 tahun 2014 tentang jabatan fungsional pranata humas dan angka kreditnya). Jurnal Universitas Paramadina, 11 (3), 1147-1163. Diakses dari https://journal.uny.ac.id/index.php/j mp/article/view/3644

Kent, M. L., \& Taylor, M. (2007). Beyond excellence: Extending the generic approach to international public relations the case of Bosnia. Public Relations Review, 33, 10-20.

Kementerian Pendayagunaan Aparatur Negara dan Reformasi Birokrasi. (2011).

Kementerian

Pendayagunaan Aparatur Negara dan Reformasi Birokrasi No.30/2011 tentang Pedoman Umum Tata Kelola Kehumasan di Lingkungan Instansi Pemerintah.

Kementerian Pendayagunaan Aparatur Negara dan Reformasi Birokrasi. (2014). Kementerian Pendayagunaan Aparatur Negara dan Reformasi Birokrasi No.6/2014 tentang Jabatan Fungsional 
Pranata Hubungan Masyarakat dan Angka Kreditnya.

Kriyantono, R. (2006). Teknik Praktis Riset Komunikasi: Disertai Contoh Praktis Riset Media, Public Relations, Advertising, Komunikasi Organisasi, Komunikasi Pemasaran. Jakarta: Kencana Prenadamedia Group.

Kriyantono, R. (2015). Konstruksi humas dalam tata kelola komunikasi lembaga pendidikan tinggi di era keterbukaan informasi publik. Jurnal Pekommas, 18 (2), 117-126.

Kriyantono, K. (2016). Public Relations Writing: Teknik Produksi Media Public Relations dan Publisitas Korporat. Jakarta: Prenamedia Group.

Morissan. (2014). Manajemen Public Relations: Strategi Menjadi Humas Profesional. Jakarta: Kencana Prenadamedia Group.

Meintjes, C., \& Grobler, A. F. (2014). Do public relations professionals understand corporate governance issues well enough to advice companies on stakeholder relationship management?. Public Relations Review, 40, 161-170. Diakses dari http://dx.doi.org/10.1016/j.pubrev.2 $\underline{013.10 .003}$

Moss, D., Likely, F., Sriramesh, K., \& Ferrari, M, A. (2017). Structure of the public relations/communication department: Key finding from a global study. Public Relations Review, 43, 80-90. Diakses dari http://dx.doi.org/10.1016/j.pubrev.2 $\underline{016.10 .019}$

Nelisna, M. (2014). Jurnal Penelitian dan Pengembangan Komunikasi dan Informatika, 5 (1), 39-50. Diakses dari

https://media.neliti.com/media/publ ications/122647-ID-the-role-ofpadang-local-government-publ.pdf Neuman, W. L. (2013). Metodologi Penelitian Sosial: Pendekatan Kualitatif dan Kuantitatif Edisi 7. Penerjemah: Edina T. Sofia. Jakarta: Indeks.

Pemerintah Provinsi Kepulauan Bangka Belitung. (2017). Babelprov.go.id. Diakses dari http://www.babelprov.go.id/

Pemerintah Provinsi Kepulauan Bangka Belitung. (2016). Peraturan Gubernur Kepulauan Bangka Belitung No.58/2016 tentang Kedudukan, Susunan Organisasi, Tugas dan Fungsi, Serta Tata Kerja 
Dinas Daerah Provinsi Kepulauan Bangka Belitung.

Rachmadi, F. (1994). Public Relations Dalam Teori Dan Praktek. Jakarta: Gramedia.

Sriramesh, K., \& Vercic, D. (2003). The Global Public Relations Handbook: Theory, Research, and Practise. Lawrence Erlbaum Associate, Publishers Mahwah New Jersey. London.
Sarosa, S. (2012). Penelitian Kualitatif: Dasar-Dasar. Jakarta: PT Indeks. Wilcox, D. L., Ault, P. H., \& Agee, W. K. (2011). Public Relations: Strategi dan Taktik. Jakarta: Karisma Publishing Group. 